\title{
The Effects of Eyestalk Ablation on the Reproductive and Immune Function of Female Macrobrachium americanum
}

\section{Aguiñaga-Cruz Jazmín Asusena, Sainz-Hernández Juan Carlos*, Fierro-Coronado Jesús Arturo and Diarte- Plata Genaro}

Centro Interdisciplinario de Investigación para el Desarrollo Integral Regional, Instituto Politécnico Nacional-Unidad Sinaloa (CIIDIR IPN-SINALOA) Departamento de Acuacultura, Blvd. Juan de Dios Bátiz Paredes \# 250, Guasave, Sinaloa, México. C. P. 81101.

\begin{abstract}
Eyestalk ablation is the most common procedure used to induce crustacean reproduction in commercial hatcheries. However, other physiological and metabolic processes are affected by the removal of the X-organ sinus gland complex located in the eyestalk. In this study, the effect of unilateral eyestalk ablation on the concentration of several hemolymph metabolites, reproduction and immune function in female Macrobrachium americanum was investigated. Molting cycle time was not significantly $(P=0.17)$ shortened in eyestalk-ablated females. However, an increased number of molts was observed in the eyestalk-ablated group because survival was significantly higher due to increased passivity and lowered aggression. As $M$. americanum has closed thelyca, reproduction was not accelerated after eyestalk ablation compared to control prawns. Food intake $(P=0.007)$ and oxygen consumption $(P=0.047)$ were both higher in eyestalk-ablated females. Concentrations of protein and glucose in hemolymph were not affected $(P=0.54$ and $P=0.19$, respectively), indicating that the demand for these metabolites was met. Glucose was metabolized by aerobic metabolism as shown by the lower lactate concentration $(P=0.02)$ and higher respiration rate after ablation. Protein was metabolized for growth as revealed by the $100 \%$ higher growth rate in eyestalkablated females $(P=0.017)$. Triglycerides were more highly concentrated $(P=0.02)$ in eyestalk-ablated females. This difference was most likely due to being transported from the digestive gland to the gonad.By analyzing the immune system it was observed that only the total hemocyte count was higher $(P=0.002)$ in eyestalk-ablated females. The protein content in hemocytes, the prophenol oxidase system and the coagulation time were not affected. In conclusion, the eyestalk ablation procedure did not cause female $M$. americanum to have more reproductive events over time. Despite this failure to accelerate reproduction, eyestalk ablation reduced aggression, and thus increased survival, and promoted superior growth. This result suggests that eyestalk ablation is promising for the cultivation of M. americanum.
\end{abstract}

Keywords: Macrobrachium americanum; Eyestalk ablation; Reproduction; Immunology

\section{Introduction}

Since 1970, eyestalk ablation (EA) has been used to improve the production of Penaeus spp. larvae in aquaculture [1,2]. In the white shrimp Litopenaeus vannamei, Macrobrachiumrosenbergii, Farfantepenaeus aztecus [3] and Farfantepenaeus duorarum [4], eyestalk ablation promotes several metabolic changes that improve reproductive performance. The X Organ Sinus Gland (XOSG), located in the eyestalks, is the principal neuroendocrine gland in crustaceans $[5,6]$. In this gland, hormones are synthesized, stored and secreted to the hemolymph in order to regulate metabolic processes [6] including vitellogenesis $[2,7,8]$, food intake [9], digestion, nutrient transport [10], molting [11], metabolism of lipids [12,13] and regulation of glucose and proteins $[12,14-16]$. Synchrony among these different metabolic processes is essential to ensure normal gonad maturation, copulation, fecundity and larvae development.

In crustaceans with closed thelycum, in addition to the metabolic synchrony needed for the collection, absorption, and integration of nutrients to the ova and to fulfill energy demands after EA, the reproduction process must match the molt cycle. Only during this time females become detached from the exuvia, permitting copulation [17]. Studies on eyestalk removal in prawns have revealed that in some species, such as Macrobrachium lanchesteri [18] and Cryphiops caementarius [19], molt cycle time is not significantly different compared to organisms with intact eyestalks, and their reproduction rate is not improved. Conversely, in other species such as M. rosenbergii [20] and $M$. acanthurus [21], the molting cycle time is shortened, allowing females to produce a higher quantity of eggs over time. M. americanum is a captured prawn with great potential for aquaculture, reaching a length of $30 \mathrm{~cm}$ and a weight of $250 \mathrm{~g}$. In addition, these prawns have thin exoskeletons, an attractive presentation and a delicious flavor [22]. In the northern part of Mexico, M. americanum reproduces for 3-4 months, from May to August. It is of scientific significance to determine if the procedure of eyestalk ablation may result in more reproductive events during the reproductive season.

In addition to the reproductive effects of $\mathrm{EA}$, a few prior studies have analyzed the immunologic consequences associated with this procedure [23-25]. Despite numerous studies on the prophenol oxidase (proPO) activating system (for reviews, see [26,27], little information exists on how it is controlled by endocrine system. After EA, changes to hemocyte count, coagulation and the proPO system have been reported in some crustaceans, but not in others. In insects, it is known that ecdysone modulates the expression of proPO-activating enzymes at the mRNA level $[28,29]$. In crustaceans, ecdysone from the Y-organ is

*Corresponding author: Sainz-Hernández Juan Carlos, Centro Interdisciplinario de Investigación para el Desarrollo Integral Regional, Instituto Politécnico NacionalUnidad Sinaloa (CIIDIR IPN-SINALOA) Departamento de Acuacultura, Sinaloa, México, Tel./Fax: +52 6878729626 and 29625; E-mail: jsainz@ipn.mx

Received August 27, 2012; Accepted October 17, 2012; Published October 25 , 2012

Citation: Asusena ACJ, Carlos SHJ, Arturo FCJ, Genaro DP (2012) The Effects of Eyestalk Ablation on the Reproductive and Immune Function of Female Macrobrachium americanum. J Aquacult Res Dev 3:156 doi:10.4172/2155 9546.1000156

Copyright: () 2012 Asusena ACJ, et al. This is an open-access article distributed under the terms of the Creative Commons Attribution License, which permits unrestricted use, distribution, and reproduction in any medium, provided the original author and source are credited. 
under the control of the sinus gland [11], and could have a similar role as in insects. However, this has not yet been established. Coagulation is part of the humoral immune response [30,31] in crustaceans, but information regarding its modulation by the endocrinal system is scarce. The aim of this study was to evaluate if the technique of unilateral eyestalk ablation promoted the acceleration of reproduction and to determine its effect on the immune system in females of the prawn M. americanum.

\section{Methods}

\section{Sample collection}

Prawns were captured at El Opochi, Sinaloa de Leyva, Sinaloa, México, at $107^{\circ} 27^{\prime} 56^{\prime \prime}$ and $108^{\circ} 40^{\prime} 22^{\prime \prime}$ west (longitude), $25^{\circ} 39^{\prime} 54^{\prime \prime}$ and $26^{\circ} 25^{\prime} 49^{\prime \prime}$ north (latitude). Sixty females and 20 males were captured using homemade cylindrical metal traps with a $2.5 \mathrm{~cm}$ net. The traps were deployed at sunset and collected early the next morning. Captured prawns were transported to Centro Interdisciplinario de Investigación para el Desarrollo Integral Regional (CIIDIR) in Guasave, Sinaloa, México. They were acclimated in 1000-L plastic containers (Rotoplas ${ }^{\mathrm{TM}}$ Model BEC-1000L, Zona Industrial Santa Rosa, Los Mochis, Sinaloa, México) with $500 \mathrm{~L}$ of municipal water. Polyvinyl chloride tubes were given as shelter. The density of organisms per container was 12, with 2 males and 10 females. Prawns were fed daily ad libitum for 15 days with a mix of $80 \%$ Oreochromis niloticus (Linnaeus, 1758) fish meat (cultured at CIIDIR) and $20 \%$ shrimp pellets (Purina ${ }^{\mathrm{TM}} 35 \%$ protein, Agribrands Purina, México S.A de C.V. Delegación A. Obregón, México D.F.). Aeration was constantly supplied, the light/dark regime was $14 \mathrm{~h} / 10 \mathrm{~h}$ and the temperature was $29 \pm 3^{\circ} \mathrm{C}$.

\section{Eyestalk ablation (EA)}

To analyze the effect of unilateral EA and removal the OXSG in $M$. americanum, the EA procedure was performed with negative stimulus reduction modification, as previously described [32]. Before ablation, xylocaine gel (AstraZeneca ${ }^{\mathrm{TM}} 5 \%$ xylocaine, Naucalpan de Juárez, Edo. Mex. México) was applied with cotton and spread around the ocular peduncle. Then, the base of the peduncle was cut, squashing it to push out the XOSG. Instead of using a coagulant, the traumatized area was covered to prevent bleeding. Coagulation occurs within $35 \mathrm{~s}$ in "normal" organisms; therefore, to reduce bleeding, the traumatized area was covered (under water) for the same amount of time in this group. The control group was manipulated but their eyestalks were not ablated. The EA group consisted of 17 females distributed in two containers and the control group consisted of 20 females distributed in two containers. Only organisms in the intermolt stage [6] were included.

\section{Molt events}

M. americanum has closed thelycum, mating only occurs when females shed their exoskeleton. Thus, it was important to establish if eyestalk ablation could promote the acceleration of the molt cycle and the possibility of more reproductive events. Molt events were registered daily in both the EA and control groups. To identify each organism, a numbered tag was attached to the dorsal section of the cephalothorax. This tag is lost with the exoskeleton during molting, and then reattached when the new exoskeleton hardened. The duration of the molt cycle and the number of molts were recorded for each organism in both groups.

\section{Reproductive index}

Recent molted females from both groups were registered and observed for spawning. Reproductive index was obtained with the equation: number of spawning/number of molts=Reproductive index.

\section{Food intake}

During the experiment, both the EA and control groups were fed $10 \%$ of their total biomass (grams) daily. Food consisted of $80 \%$ fish meat and $20 \%$ shrimp pellets. This quantity of food is more than is required per individual, allowing us to estimate food intake by measuring the amount of leftover food after $24 \mathrm{~h}$. The equation used to estimate intake was as follows: total food-leftover food=intake, expressed in grams of food intake per gram of prawns.

\section{Growth rate}

Two days previous the eyestalk ablation, and monthly, organisms were weighed utilizing an Ohaus $\mathrm{HH}$ series scale. Growth rate was calculated by the equation:

(final weight - initial weight)/time (months) $=$ Growth rate

\section{Oxygen consumption}

Oxygen consumption was analyzed by individually placing 6 EA and 6 control prawns in a breeding chamber as previously described [33]. Oxygen levels were saturated and stabilized at $6 \mathrm{mg} / \mathrm{L}$. Then, the system was closed and the oxygen consumption was recorded every 30s. The analysis was concluded when the oxygen concentration reached $2 \mathrm{mg} / \mathrm{L}$. Consumed oxygen in each measurement was reported

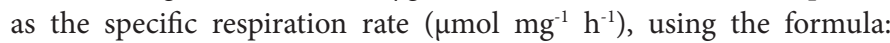

$$
=\frac{(C c-C a) \cdot V}{t \cdot \mathrm{mg} \text { of prawns }}
$$

Where $C c$ and $C a$ are the oxygen concentrations $\left(\mathrm{mg}^{-1}\right)$ of the chamber with controls and with animals, respectively, $t$ is the incubation period ( $\mathrm{min})$ and $V$ is the volume of the chamber $(\mathrm{ml})$.

\section{Coagulation}

Coagulation was analyzed by withdrawing hemolymph from the ventral sinus without an anticoagulant solution. Hemolymph was placed on a glass slide and shook slowly until jellification. The time between hemolymph withdrawal and jellification was considered the coagulation time.

\section{Hemolymph samples}

Hemolymph samples for metabolic and immunologic testing were collected at 5 days after the eggs harvest, approximately 20 days from the last molt, in the morning before feeding. This period was chosen believing that the females would not be distracted by taking care of the eggs that they are carrying or by the process of molting. At this time, the females were considered to be focused on eating and gonad development. Hemolymph was sampled utilizing an anticoagulant solution $(0.34 \mathrm{M} \mathrm{NaCl}, 30 \mathrm{mM}$ trisodium citrate; $\mathrm{pH} 7.5) 2: 1$ to hemolymph [34].

\section{Total hemocyte count (THC)}

Hemolymph was diluted 1:10 with an anticoagulant solution and $4 \%$ Formaldehyde. From this solution, hemocytes were counted in triplicate in a Newbauer chamber under a light microscope. The THC was reported as the number of hemocytes per $\mathrm{ml}^{-1}$ of hemolymph.

\section{Analysis of plasma and cell content}

Cells from the original 2:1 solution were separated from the plasma by centrifugation at $800 \mathrm{~g}$ and washed once with anticoagulant solution. Then, the cells' contents were recovered by centrifugation at $12,000 \mathrm{~g}$ 
for $30 \mathrm{~min}$, in a 1:1 volume of withdrawn hemolymph to cacodylate buffer $(10 \mathrm{mM}$ sodium cacodylate, $\mathrm{pH} 7)$. Cells were analyzed to measure proPO. Plasma was used for the measurement of glucose, lactate, triglycerides, protein and the immunologic indicator PO. A standard curve was constructed prior to metabolite analysis. Twenty $\mu \mathrm{L}$ of the sample were analyzed in triplicate. Absorbance was measured for glucose $(490 \mathrm{~nm})$, lactate $(535 \mathrm{~nm})$ and triglycerides $(490 \mathrm{~nm})$ using commercial kits from RANDOX (Crumling, United Kingdom). Protein was quantified using the Bradford method [35]

\section{Determination of proPO content and PO activity}

Phenol oxidase activity was determined by recording the formation of dopachrome from L-dihydroxiphenylalanine, a reaction catalyzed by PO [36]. Fifty $\mu \mathrm{l}$ cacodylatebuffer was added to $50 \mu$ l plasma. Then, 50 $\mu \mathrm{L}$-dopa $\left(3 \mathrm{mg} \mathrm{ml}^{-1} \mathrm{dH} 2 \mathrm{O}\right)$ was added. The solution was incubated for $10 \mathrm{~min}$ at $25^{\circ} \mathrm{C}$, then $800 \mu \mathrm{l}$ cacodylate buffer was added. The absorbance was measured, and cacodylate buffer was used as a control. Total activity was expressed as the change in absorbance at $492 \mathrm{~nm}$ $\mathrm{min}^{-1} \mathrm{ml}^{-1}$ of hemolymph sampled.

To determine proPO content, the proPO sample was first activated to $\mathrm{PO}$ with trypsin $\left(0.1 \mathrm{mg} \mathrm{ml}^{-1}\right.$ in distilled $\left.\mathrm{H}_{2} \mathrm{O}\right)$, then $\mathrm{PO}$ activity was determined as described previously. ProPO and $\mathrm{PO}$ were analyzed separately in the plasma and the cellular pellet. However, data obtained for both fractions were summed to correct for the accidental degranulation or rupture of hemocytes.

The significance of the variables was evaluated by the one way ANOVA test and a posteriori Tukey Test. The level of significance was $\propto=0.05$.

\section{Results}

Survival was higher in females in the EA group than those in the control group (Figure 1). The counts of the number of molts per group showed that the EA group had 32 molts and the control group had 24 molts (Table 1). The molt cycle was not significantly reduced in time $(P=0.17)$ when females underwent unilateral EA (Table 1$)$.

Food intake was significantly higher in females in the EA group than in the controls $(P=0.007)$ (Table 1$)$, growth was significantly higher in EA females too $(P=0.017)$ (Table 1$)$. In addition, oxygen consumption was significantly higher in females in the EA group $(P=0.047)$ than in the control group (Table 1). No significant difference was observed in the concentration of glucose $(P=0.19)$ (Table 1$)$. The concentration of lactate was significantly lower $(P=0.02)$ in the EA group than in the control group (Table 1$)$. Triglycerides were significantly higher $(P=0.02)$ in the EA group than in the control group (Table 1). No significant

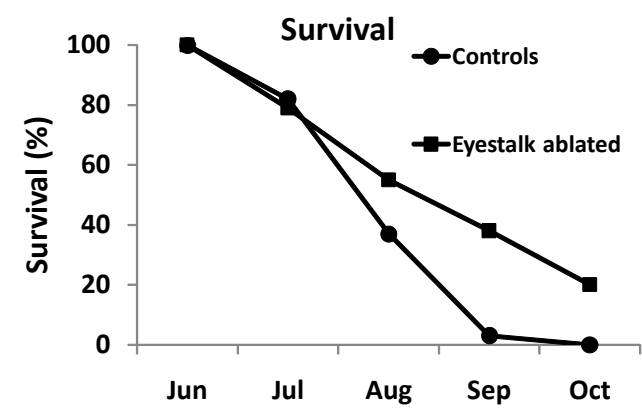

Figure 1: Survival of both control and eyestalk ablated groups. Initial $\mathrm{N}$ for control and eyestalk ablated group $=20$ and 17 prawns respectively.

\begin{tabular}{|c|c|c|c|}
\hline & Control & Eyestalked & \\
\hline No. of Molts & 24 & 32 & * \\
\hline Molt cycle (days) & $31.3 \pm 3.4$ & $29.4 \pm 5.5$ & \\
\hline Ingesta (g food x g prawn) & $0.046 \pm 0.016$ & $0.056 \pm 0.02$ & * \\
\hline $\begin{array}{l}\text { Growth rate } \\
\text { (g x month) }\end{array}$ & $2 \pm 0.35$ & $4 \pm 0.6$ & * \\
\hline Respiration rate $\left(\mu \mathrm{mol} \mathrm{mg}^{-1} \mathrm{~h}^{-1}\right)$ & $2.3 \pm 1.1$ & $3.8 \pm 0.9$ & * \\
\hline Glucosa $\left(\mathrm{mg} \cdot \mathrm{dl}^{-1}\right)$ & $38.1 \pm 17$ & $32 \pm 20$ & \\
\hline Lactato $\left(\mathrm{mg} \cdot \mathrm{dl}^{-1}\right)$ & $34.9 \pm 17$ & $22.9 \pm 18$ & * \\
\hline Protein $\left(\mathrm{mg} \cdot \mathrm{dl}^{-1}\right)$ & $364 \pm 145$ & $393 \pm 213$ & \\
\hline Trigliceridos $\left(\mathrm{mg} \cdot \mathrm{dl}^{-1}\right)$ & $64.6 \pm 17.2$ & $78.9 \pm 19.3$ & * \\
\hline
\end{tabular}

Table 1: Variables associated to the eyestalk ablation. Number of molts was registered during four month. Average and standard deviation are presented. * indicate significant differences.

\begin{tabular}{|l|l|l|l|}
\hline & Control & Eyestalked & \\
\hline Coagulation (S) & $38.45 \pm 10.14$ & $41.45 \pm 11.16$ \\
\hline THC & $10.92 \pm 1.39$ & $16.3 \pm 5.68$ & $*$ \\
\hline Protein $\left(\mathrm{mg} \mathrm{ml}^{-1}\right)$ & $18.67 \pm 6.25$ & $17.88 \pm 4.75$ \\
\hline ProPO (Ab.t.Vol) & $3.74 \pm 2.04$ & $4.67 \pm 2.62$ & \\
\hline PO (Ab.t.Vol) & $6.98 \pm 1.56$ & $7.34 \pm 1.26$ \\
\hline Whole PO & $10.73 \pm 3.61$ & $12.02 \pm 3.89$ \\
\hline
\end{tabular}

Table 2: Immune variables analyzed after eyestalk ablation. $\mathrm{THC}=$ Total Hemocyte Count, proPO=prophenol-oxidase, $\mathrm{PO}=$ phenol-oxidase, $\mathrm{S}=$ seconds

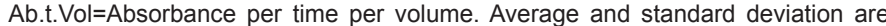
presented. * indicate significant differences.

difference in the plasma protein concentration was found between the two groups $(P=0.54)$ (Table 1$)$.

In regards to the immune system, only the hemocyte count was significantly different $(P=0.002)$ (Table 2$)$. No significant difference was detected between groups in any other variable, including protein concentration from the hemocytes' contents $(P=0.4)$, coagulation time $(P=0.97)$, total activity of proPO $(P=0.3)$, total activity of $\mathrm{PO}(P=0.47)$ and total activity of whole $\mathrm{PO}(P=0.25)$ (Table 2).

\section{Discussion}

Unilateral eyestalk ablation is a common practice to induce ovary maturation in many difficult-to-spawn, closed-thelycum female prawn brood stock species such as F. aztecus, F. duorarum, Penaeus monodon (Fabricius, 1798) and P. orientalis (Gmelin, 1790) $[37,38]$. This practice can be successfully applied during the reproductive season, as well as during the off-season, to promote spawning [39]. Analysis performed in this study demonstrated that the metabolism of $M$. americanum was not influenced to accelerate reproduction following EA.

Crustaceans with closed thelycum must first shed the exuvia to expose the thelycum for mating. An acceleration of the molt cycle was expected in M. americanum, similar to that occurring in M. rosenbergii; however, this was not the case. Molt frequency must increase if females are to produce more eggs per over time. In addition, maturation of the gonad must be accelerated. Both of these processes have to be synchronized before mating and producing viable fertilized eggs. Unilateral EA has previously been shown to have different effects on the length of the molt cycle in prawns.

A decrease in the duration of the molt cycle following EA is primarily attributed to a lowered concentration of molt-inhibiting hormone (MIH) caused by EA. Sinus gland extracts or recombinant MIH inhibit ecdysteroid biosynthesis [40-42]. Thus, in EA prawns, 20-hydroecdysone (20E) should be synthesized and secreted at a higher rate. In the prawns Marsupenaeus japonicas and M. rosembergii 
[20,43] and shrimps Farfantepenaeus aztecus and Litopenaeus vannamei $[25,38]$, molting and gonad development are accelerated and synchronized for mating and the production of larvae. An increased molt frequency has been reported in Homarus americanus but only after bilateral EA [44]. Conversely, studies on Litopenaeus stylirostris [45] and other crustaceans [46] have failed to note a decrease in molt cycle duration after EA. It has been suggested that these results were a consequence of the molt stage or reproductive stage of the shrimp at the time of EA [47]. To standardize the procedure in this experiment, EA was performed during the intermolt stage. In Macrobrachium diggetii, the molt cycle length did not change, although metabolites associated with egg maturation were more highly concentrated in hemolymph. This finding indicates that while egg development was accelerated, reproduction was not accelerated. In $M$. lanchesteri, a similar increase in molt frequency was not apparent, but a significant increase in the food conversion rate between normal, unilateral and bilateral EA individuals was reported [18].

In EA $M$. americanum females, there was not a reduction in the length of the molt cycle. However, based on the higher food intake, elevated oxygen consumption and increased growth following ablation, these prawns' metabolism was clearly accelerated. An increase in food intake promotes the elevation of protein concentration in hemolymph that can be utilized for energy production or growth [48]. In $M$. americanum, protein from food appeared to be utilized for growth because the EA group registered 100\% more growth than controls. Furthermore, the relationship between intake and metabolized protein did not change the protein concentration in M. americanum hemolymph. This suggests protein equilibrium and sufficient supply to support the demand for growth by the unilateral EA group. Protein could be used for vitellogenin synthesis, but the main consumption of protein could be growth. Eyestalk ablation induces gonadal maturation due to the fact that vitellogenesis is negatively controlled by vitellogenesis-inhibiting hormone (VIH), produced by the XOSG complex in the eyestalks [49]. In previous studies, contradictory results were obtained regarding the effect of EA on protein levels in the hemolymph of penaeid shrimps. It was reported that protein levels decreased by $50 \%$ in unilaterally EA Farfantepenaeus paulensis (Pérez Farfante) females [23]. In contrast, another report $[24,25]$ noted a non-significant increase in protein in unilaterally EA L. vannamei females.

Glucose concentration in hemolymph was also not significantly different between the EA and control groups, despite the high rate of food intake. This finding indicates that energetic demands were supplied by the food, thus maintaining a stable concentration of glucose in the hemolymph. A previous study in EA shrimp found differences between the sexes in the efficiency of energy use and concluded that this difference was related to the different reproductive efforts in males and females [50]. In this study, evidence suggested that glucose was mainly utilized to produce energy by oxidative metabolism and was not utilized for muscle activity. Data contributing to this assumption was the low lactate concentration, the high rate of oxygen consumption and the passivity shown by prawns after EA. It is well known that crustacean hyperglycemic hormone $(\mathrm{CHH})$ secreted from the XOSG stimulates hyperglycemia [51]. However, it is not clear if $\mathrm{CHH}$ controls the baseline levels of circulating glucose because EA does not necessarily modify these levels. In lobsters Panulirus argus, only bilaterally and not unilaterally ablated specimens had lower hemolymph glucose levels [52]. This suggests that unilateral EA is not sufficient to deplete the hemolymph of circulating $\mathrm{CHH}$ to the extent that glucose levels would decrease below baseline. Controversial results have been reported regarding the glucose concentration in the crab Chasmagnathus granulate [53,54]. The latter authors attributed this discrepancy to the methods used for glucose analysis because the reduced levels occurred only when a specific enzymatic procedure was used. In Macrobrachium malcolmsonii (Milne Edwards) unilateral EA had no significant effect on the body carbohydrate content, even when fed with different foods [55].

Increased food ingestion is common in ablated penaeids $[9,18]$. The signal for ingestion is prompted by the energy demand, via the endocrine system [56], and the main hormone involved is the $\mathrm{CHH}$. $\mathrm{CHH}$ promotes glycogenesis in the digestive gland and muscles $[14,56]$. After EA, metabolism is altered; glucose is stored as glycogen and the cellular demand for glucose rises without the possibility of resultant hyperglycemia from the hormone $\mathrm{CHH}[17,53,56]$. An alternative method to support the demand for energy is increasing food intake and obtaining carbohydrates from food.

Triglycerides were detected at high concentrations in the hemolymph of EA $M$. americanum females. Ablation appears to increase the contribution of the hepatopancreas to lipid accumulation in the vitellogenic ovary [57,58], although captive conditions (including diet) may also play a role in this increase [57]. The lipid content of the EA and intact control M. malcomsonii fed with adult Artemias pp was significantly higher compared to other foods [54]. Lipids from food are mainly stored in the digestive gland as triglycerides. When lipids are required for structural components, energy or reserves in eggs, they are transported from the digestive gland to the target tissue or the gonad [59]. Gonad development was not recorded in this experiment because its characteristics in live animals are not clear, but it was wise thinking in those triglycerides as associated to the gonad maturation as a possible explanation. In M. malcolmsonii the levels of protein and lipids, but not carbohydrates, were altered significantly after unilateral EA [54]. Another study reported EA caused marked changes in hemolymph glucose, glycogen, protein, total lipids and glycerol in the tissues of Metapenaeus monoceros (Fabricius) [60].

The EA group exhibited higher survival rates than the control group during this experiment. EA not only alter hormones, it also results in severe trauma, destruction of a mayor portion of the nervous system and renders the animal blind $[11,61]$. In this experiment, no mortality occurred during the process of EA or $48 \mathrm{~h}$ post-EA. Mortality in $M$. americanum was more commonly related to attacks between animals. Although their respiratory rate was elevated, EA prawns showed an unusual passivity, thus explaining our result. Conversely, the control group showed more activity and attacks between prawns. Because M. americanum is territorial, the more active control prawns had more encounters and fights. Therefore, aggressiveness was the main cause of mortality. In other prawns such as $M$. lanchesteri, the mortality rate in ablated prawns was higher than that of intact prawns [62]. The unusual passivity is not in accordance with results reported in other crustaceans including Orconectes limosus and Cambarus sp. [63]. During unilateral EA, neurodepressing hormone $(\mathrm{NDH})$ is partially eliminated. This hormone regulates the diurnal cycle and depresses the motor and sensory systems of the organism $[7,10,63]$. EA promotes hyperactivity because the lack of NDH. However, in M. americanum, the result was the opposite. These prawns showed passivity and low lactate concentration, indicating that for some reason mechanical activity was not promoted and glucose was not metabolized anaerobically.

In vertebrates, it is clear that the immune system is not autonomous. Rather, this system is connected to the nervous and endocrine systems, constituting a multisystem $[64,65]$. In invertebrates, the functional relationship between the immune, endocrine and nervous systems is 
not known. The XOSG is a neuroendocrine center that produce neurohormones regulating reproduction as well as metabolic processes such as osmotic and ionic balance [66], energy supply [50], molt [20] and social control [67]. Therefore, it is expected that EA resulted in direct or indirect consequence on the immune system. Unilateral EA has promoted different changes in the immune system of several crustacean species, however, no changes were detected in other species. In most crustaceans, bilateral EA caused a general alteration in immune system function $[24,68]$. One study found that when recombinant $\mathrm{CHH}$ from L. vannamei was administered to this same species, it increased glucose and also improved immunologic response [69]. THC, PO, serum protein levels and clearance ability of Vibrio harveyi were higher than controls. In F. paulensis females, there was a $43.7 \%$ reduction in the THC 1 week after unilateral EA [23]. In other studies by [24] and [25] on L. vannamei, a non-significant decline in THC was observed. In Drosophila melanogaster (Meigen, 1830) [70] found that the lack of ecdysteroids compromised the cellular immune response and reduced hemocyte proliferation and encapsulation. However, these data contrast with our results. We found that EA M. americanum females exhibited a statistically significant increase in THC compared to the control group.

To date, two different coagulation mechanisms have been characterized in molecular detail in invertebrates. These mechanisms are the hemocyte derived clotting cascade in the horseshoe crab Tachypleus tridentatus [71] and the transglutaminase (T-Gase)-dependent clotting reaction in the crayfish $P$. leniusculus [72-73]. The clotting system of $M$. americanum females was not found to be affected by unilateral EA.

Despite numerous studies on the proPO activating system [26-27], little information exists regarding its control by the endocrine system. In M. americanum females, immunologic variables such as proPO and PO activity were not affected by unilateral EA. Similar results were reported by [23], they did not detect a significant change in PO activity in P. paulensis females after ablation. Another study [24] did not find a significant difference in PO activity following unilateral EA in $L$. vannamei. In addition to participating in the internal defense system, the enzyme PO participates in the process of cuticular melanization in crustaceans [74]. Sainz-Hernández JC [25] reported a decrease in PO activity in bilaterally EA L. vannamei, and the acceleration of the molting process caused by EA presumably also produces increased melanin production via the PO system. In the present study, females did not accelerate the molt cycle. Although PO is implicated in the molting process, PO activity was unchanged in either group. In Panulirus homarus, PO activity decreased after a week of EA, but THC did not [68].

\section{Conclusions}

The EA procedure does not accelerate reproduction in $M$. americanum females. As this species has closed thelycum, it was of interest to accelerate the molt period; however, it was unaltered following ablation. EA prawns survived longer than control prawns, thus more molts were observed in the EA group. The use of EA in $M$. americanum aquaculture may be favorable and encouraged. Survival and food intake are relevant variables for optimal aquaculture, not due to increased reproduction but due to increased biomass harvest.

\section{Acknowledgments}

The authors greatly appreciate the animal supply help offered by members of the local community in El Opochi, Sinaloa de Leyva, México, who were the first to be interested in this project. This work was supported by Instituto Politécnico Nacional (Project no. 20100328) and Consejo Estatal de Ciencia y Tecnología de Sinaloa. Jazmin Aguiñaga received a grant from CONACyT (332431).

\section{References}

1. Bray W, Lawrence A (1992) Reproduction of Penaeus species in captivity. In Fest AW and Lester LJ (Eds) Marine shrimp culture: Principles and practices. Elsevier pp: 93-170.

2. Subramoniam T (2011) Mechanisms and control of vitellogenesis in crustacean. Fisheries Science 77: 1-21.

3. AQUACOP (1977) Observation on the maturation and reproduction of penaeid shrimp in captivity in a tropical medium. Aquaculture Workshop ICES, France.

4. Caillouet WC (1972) Ovarian maturation induced by eyestalk ablation in the pink shrimp Penaeus duorarum Burkenroad. Proceedings of the World Mariculture Society 3: 205-225.

5. Beltz BS (1988) Crustacean neurohormones. In: Endocrinology of Selected Invertebrate Types, Invertebrate Endocrinology,Vol. 2. Alan R Liss, New York.

6. Chang ES (1992) Endocrinology. In: Fast AW, Laster J (Eds) Marine shrimp culture: Principles and Practices. Elsevier, Amsterdam.

7. Fingerman M (1995) Endocrine mechanisms in crayfish, with emphasis on reproduction and neurotransmitter regulation of hormone release. American Zoology 35: 68-78.

8. Palacios E, Carreno D, Rodrigez-Jaramillo MC, Racotta IS (1999) Effect of eyestalk ablation on maturation, larval performance, and biochemistry of Penaeus vannamei broodstock. Journal of Applied Aquaculture 9: 1-23.

9. Taylor J, Vinatea L, Ozorio R, Schuweitzer R, Andreatta ER (2004) Minimizing the effects of stress during eyestalk ablation of Litopenaeus vannamei females with topical anesthetic and a coagulating agent. Aquaculture 233: 173-179.

10. Rosas C, Bolongaro-Crevenna A, Sanchez A, Gaxiola G, Soto L, et al. (1995) Role of the digestive gland in the energetic metabolism of Penaeus setiferus. Biol Bull 189: 168-174.

11. Chang ES, O'Connor JD (1988) Crustaceanmolting. In: Endocrinology of Selected Invertebrate Types, Invertebrate Endocrinology, Vol. 2. Alan R Liss New York

12. Teshima SI, Kanazawa A, Kushio S, Horinouchi K (1988) Lipid metabolism in destalked prawn Penaeus japonicus: Induced maturation and accumulation of lipids in the ovaries. Nippon Suisan Gakk 54: 1115-1122.

13. Santos EA, Nery LE, Keller R, Goncalves AA (1997) Evidence for the involvement of the crustacean hyperglycemic hormone in the regulation of lipid metabolism. Physiol Zool 70: 415-420.

14. Santos EA, Keller R (1993a) Crustacean hyperglycemic hormone $(\mathrm{CHH})$ and the regulation of carbohydrates metabolism: Current perspectives. Comparative Biochemistry and Physiology 106: 405-411.

15. Santos EA, Keller R (1993b) Regulation of circulating levels of the crustacean hyperglycemic hormone: evidence for a dual feedback control system. J Comp Physiol 163: 374-379.

16. Chen JC, Cheng, SY (1995) Hemolymph oxygen content, oxyhemocyanin, protein levels and ammonia excretion in the shrimp Penaeus vannamei exposed to ambient nitrite. J Comp Physiol 164B: 530-535.

17. Ruppert EE, Barnes RD (1996) Zoología de los Invertebrados. $6^{\text {th }}$ eddition. McGrawn-Hill-Interamericana. México, D.F.

18. Ponnuchamy R, Ravichandra R, Shakuntala K (1980) Effects of eyestalk ablation on growth and food conversion efficiency of the freshwater prawn Macrobrachium lanchesteri (De Man). Hydrobiologia 77: 77-80.

19. Reyes Avalos WE, Pilco-Plascencia M, Olortegui-Morales K (2002) Efecto de la ablación unilateral del pedúnculo ocular en la maduración ovárica y en el ciclo de muda de Cryphiops caementarius en laboratorio. Congreso Internacional Virtual de Acuacultura 681-687.

20. Okumura T, Aida K (2001) Effects of bilateral eyestalk ablation on molting and ovarian development in the giant freshwater prawn Macrobrachium rosenbergii. Fisheries Science 67: 1125-1135.

21. Cunha $\mathrm{CH}$, Miyaco YO (2010) The influence of eyestalk ablation on the reproduction of freshwater Macrobrachium acanthurus shrimp in captivity. Acta Scientiarum: Biological Sciences 32: 217-221

22. Sainz-Hernández JC (2006) Propone CIIDIR Sinaloa impulsar el cultivo de langostinos de río. Boletín de la COFAA-IPN 6: 26-27.

23. Perazzolo LM, Gargioni R, Ogliari P, Barranco MA (2002) Evaluation of some 
Citation: Asusena ACJ, Carlos SHJ, Arturo FCJ, Genaro DP (2012) The Effects of Eyestalk Ablation on the Reproductive and Immune Function of Female Macrobrachium americanum. J Aquacult Res Dev 3:156 doi:10.4172/2155-9546.1000156

Page 6 of 7

hemato-immunological parameters in the shrimp Farfantepenaeus paulensis submitted to environmental and physiological stress. Aquaculture 214: 19-33.

24. Maggioni DS, Andreatta ER, Hermes EM, Barracco A (2004) Evaluation of some hemato-immunological parameters in female shrimp Litopenaeus vannamei submitted to unilateral eyestalk ablation in association with a diet supplemented with superdoses of ascorbic acid as a form of immunostimulation. Aquaculture 241: $501-515$.

25. Sainz-Hernández JC, Racotta D, Hernandez-Lopez J, Dumas S (2008) Effect of eyestalk ablation on metabolism and immune system in shrimps. Aquaculture 283: 188-193.

26. Söderhäll K, Smith VJ (1986) The prophenoloxidase activating system: the biochemistry of its activation and role in arthropod cellular immunity, with special reference to crustaceans. In: Immunity in Invertebrates. (M. Brehelined). Springer Verlag, Berlin, pp. 208-223

27. Sritunyalucksana K, Söderhäll K (2000) The proPO and clotting system in crustaceans. Aquaculture 191: 53-59.

28. Ahmed A, Martin D, Manetti A, Man SJ, Lee,WJ et al. (1999) Genomic structure and ecdysone regulation of the prophenoloxidase $1 \mathrm{gene}$ in the malaria vector Anopheles gambie. PNAS 96: 14795-14800.

29. Zou Z, Wang Y, Jiang H (2005) Manduca sexta prophenoloxidase activating proteinase-1 (PAP-1) gene: Organization, expression, and regulation by immune and hormonal signals. Insect Biochem Mol Bio 35: 627-636.

30. Theopold U, Li D, Fabbri M, Scherfer C, Schmidt O (2002) The coagulation in insect hemolymph. Cell Mol Life Sci 59: 636-372.

31. Chun-Hung L, Chin-Chuan C, Yun-Chih C, Cheng W, Maw-Sheng Y (2011) Identification and cloning of a transglutaminase from giant freshwater prawn, Macrobrachium rosembergii, and its transcription during pathogen infection and moulting. Fish Shellfish immunol 31: 871-880.

32. Diarte-Plata G, Sainz-Hernández JC, Aguiñaga-Cruz JA, Fierro-Coronado JA, Polanco-Torres A, et al. (2012) Eyestalk ablation procedures to minimize pain in the freshwater prawn Macrobrachium americanam. Applied Animal Behavior Science 140: 172-178.

33. Torres JJ, Brightman RI, Donell J, Harvey J (1996) Energetics of larvae red drum, Sciaenops ocellatus. Part I: oxygen consumption, specific dynamic action, and nitrogen excretion. Fishery Bulletin 94: 756-765.

34. Chiu ST, Hsieh SL, Yeh SP, Jian SJ, Cheng W, et al.(2010) The increase of immunity and disease resistance of the giant freshwater prawn, Macrobrachium rosenbergii by feeding with selenium enriched-diet. Fish and Shellfish Immunology 29: 623-629.

35. Bradford MM (1976) A rapid and sensitive method for the quantitation of microgram quantities of protein utilizing the principles of protein-dye binding. Anal Biochem 72: 248-254.

36. Hernández-López, J, Gollas-Galvan T, Vargas-Albores F (1996) Activation of the prophenoloxidase system of the brown shrimp (Penaeus californienis Holmes). Comparative Biochemistry and Physiology 113: 61-66.

37. Primavera $\mathrm{JH}$ (1985) A reviews of maturation and reproduction in closed thelycum Penaeids. Proceedings of the First International Conference on the Culture of Penaeid Prawns/Shrimps, Iloilo City, Philippines, pp. 47-64.

38. Gandy RL, Samocha TZ, Masser MP, Fox JM, Abdul-Mehdli SA, et al (2007) The effect of unilateral eyestalk ablation and diet on the reproductive performance of wild-caught Farfantepenaeus aztecus (Ives, 1891) using a closed recirculating maturation system. Aquaculture Research 38:580-587.

39. Aktas M, Kumlu M, Eroldogan OT (2003) Off-season maturation and spawning of Penaeus semisulcatus by eyestalk ablation and/or temperature-photoperiod regimes. Aquaculture 228: 361-370.

40. Lachaise F, Le-Reux A, Hubert M, Lafont R (1993) The molting gland of crustaceans: Localization, activity, and endocrine control (A review). Journal of Crustacean Biology 13: 198-234.

41. Lee KJ, Watson RD (2002) Expression of crustacean (Callinectes sapidus) Molt-Inhibiting Hormone in insect cells using recombinant baculovirus. J Exp Zool 292: 41-51.

42. Zheng J, Nakatsuji T, Roer RD, Watson RD (2008) Studies of a receptor guanylcyclase cloned from Y-organs of the blue crab (Callinectes sapidus), and its possible functional link to ecdysteroidogenesis. Gen Comp Endocrinol 155 780-788.

43. Tsutsui N, Kim YK, Jasmani S, Ohira T, Wilder MN et al. (2005) The dynamics of vitellogenin gene expression differs between intact and eyestalk ablated kuruma prawn Penaeus (Marsopenaeus) japonicas. Fisheries science 71: 249256 .

44. Mauviot JC, Castell JD (1976) Moulting and growth enhancing effects of bilateral eyestalk ablation on juvenile and adult American lobster (Homarus americanus). Journal of the Fisheries Research Board of Canada 33: 1922 1929.

45. Gendrop-Funes V, Valenzuela-Espinoza E (1995) Unilateral ablation of Penaeus stylirostris (Stimpson). Ciencias Marinas 21: 401-413.

46. Carlisle DB (1953) Moulting hormones in Leander (Crustacea, Decapoda). Journal of the Marine Biological Association of United Kindom 32: 289-296.

47. Chan SM, Rankin SM, Keeley LL (1990) Effects of 20-hydroxyecdysone injection and eyestalk ablation on the moulting cycle of the shrimp, Penaeus vannamei. Comparative Biochemistry and Physiology 96: 205-209.

48. Poulieff RR (2002) Metabolismo energético en el humano, un enfoque cuantitativo. Instituto Politécnico Nacional. Mexico, PP. 106

49. Keller R (1992) Crustacean neuropeptides: structures, functions and comparative aspects. Experientia 48:439-448.

50. Rosas C, Fernández I, Brito R, Iglesias ED (1993) The effect of eyestalk ablation on the energy balance of pink shrimp, Penaeus notiales. Comparative Biochemistry and Physiology 104A: 183-187.

51. Díaz-Iglesias E, Brito R, Hernández I (1987) Efectos de la ablación del complejo neurosecretor peduncular en juveniles de langosta, Panulirus argus. II Algúnos aspectos metabólicos. Revista de Investigaciones Marinas 8: 81-93.

52. Santos EA, Colares EO (1986) Blood glucose regulation in an intertidal crab Chasmagnatus granulata (Dana, 1851). Comparative Biochemistry and Physiology 83: 673-675.

53. Santos EA, Nery LE, Manzini GC (1988) Action of the crustacean hyperglycemic hormone of Chasmagnatus granulata (Dana, 1851) (Decapoda: Grapsidae) Comparative Biochemistry and Physiology 89: 329-332.

54. Soundarpandian P, Ananthan G (2008) Effect of unilateral eyestalk ablation on the biochemical composition of commercially important juveniles of Macrobrachium malcolmsonii (H. Milne Edwards). Int J Zoo Res 4: 106-112.

55. Chang (1992) Endocrinology. In: Fest AW and Lester LJ (Eds) Marine Shrimp culture: Principles and practices. Elsevier, USA, pp. 53-91.

56. Keller R, Sedlmeier DA (1988) Metabolic hormone in crustaceans: The hyperglycemic neuropeptide. In: Endocrinology of Selected Invertebrate Types, Invertebrate Endocrinology, Vol. 2. Alan R Liss, New York.

57. Marsden G, Mather P, Richarson N (2007) Captivity, ablation and starvation of the prawn Penaeus monodon affects protein and lipid content in ovary and hepatopancreas tissues. Aquaculture 271: 507-515.

58. Vazquez-Boucard CG, Levy L, Ceccaldi HJ, Brogren CH (202) Developmenta changes in concentration of vitellin, vitellogenin and lipids in hemolymph, hepatopancreas, and ovaries from different ovaries stages of Indian white prawn Faneropenaeus indicus. J Experimental Marine Biology and Ecology 281: $63-75$.

59. Okumura T, Kim YK, Kawazoe I, Yamano K, Tsutsui N, et al. (2006) Expression of vitellogenin and cortical rod proteins during induced ovarian development by eyestalk ablationin the kuruma prawn, Marsupenaeus japonicas. Comp Biochem Physiol A Mol Integr Physiol 143: 246-253.

60. Surendranath P, Ramanaiah K, Rao KVR (1992) Effect of eyestalk extract and Kelthane on penaeid prawn Metapenaeus monoceros (Fabricus). Indian Journal of Marine Science 30: 676-679.

61. Chang ES (1989) Endocrine regulation of molting in crustacea. Aquatic Science 1: $131-157$.

62. Varalakshmi KN, Reddy R (2010) Effects of eyestalk ablation on growth and ovarian maturation of the fresh water prawns Macrobrachium lanchesteri. Turk j Fish Aquat Sci 10: 403-410.

63. Huberman A (1996) Neurodepressing hormone (NDH): factor or fiction?.Pp. 1-17. In: Crustaceana. Vol. 69. (E.J. Brill y Leiden eds). 
Citation: Asusena ACJ, Carlos SHJ, Arturo FCJ, Genaro DP (2012) The Effects of Eyestalk Ablation on the Reproductive and Immune Function of Female Macrobrachium americanum. J Aquacult Res Dev 3:156 doi:10.4172/2155-9546.1000156

64. Jankovic $V D$ (1994) Neuroimmunomodulation, from phenomenology to molecular evidence. Ann N Y Acad sci 741: 1-38.

65. Panerai AE (1994) Problems and perspectives in the approach to neuroendocrineimmuno-modulation studies. Ann N Y Acad sci 741: 81-84.

66. McNamara JC, Salomao LC, Ribeiro EA (1990) The effect of eyestalk ablation on haemolymph osmotic and ionic concentration during acute salinity exposure in the freshwater shrimp Macrobrachium olfersii (Wiegmann) (Crustacea, Decapoda). Hydrobiologia 199: 193-199.

67. Karplus L, Hulata G (1995) Social control of growth in Macrobrachium rosembergii, V. The effect of unilateral eyestalk ablation on jumpers and laggards. Aquaculture 138: 181-190.

68. Verghese B, RadhakrishnanE, Padhi A (2008) Effect of moulting, eyestalk ablation, starvation and transportation on the immune response of indian spiny lobster, Panulirus homarus. Aquaculture Research 39: 1009-1013.

69. Wanlem S, Supamattaya K, Tantikitti C, Prasertsan P, Graidist P (2011) Expression and applications of recombinant crustacean hyperglycemic hormone from eyestalks of white shrimp (Litopenaeus vannamei) against bacterial infection. Fish and Shellfish immunol 30: 877-885.

70. Sorentino RP, Carton Y, Govind S (2002) Cellular immune response to parasite infection in Drosophila lymph gland is developmentally regulated. Developmental Biology 243: 65-80.

71. Shun-Ichiro K, Tokunaga F, Kugy Y, Motoyama S, Miura Y et al (1996) Limulus factor $\mathrm{D}$, a 43-kDa protein isolated from horseshoe crab hemocytes, is a serine protease homologue with antimicrobial activity. FEBS Lett 398: 146-150.

72. Kopácek P, Hall M, Sonderhall K (1993) Characterization of a clotting protein, isolation from plasma of the freshwater crayfish Pacifastacus leniusculus. European Journal of Biochemistry 213: 591-597.

73. Hall M, Wang R, Antwerpen RV, Sottrup-Jensen L, Sonderhall K (1999) The crayfish plasma clotting protein: a vitellogenin-related protein responsible for clot formation in crustacean blood. Pro Natl Acad Sci USA 96:1965-1970.

74. Benjakul S, Visessanguan W, Tanaka M (2005) Properties of phenooxidase isolated from the cephalotorax of Kumura prawn (Penaeus japonicus). Journal of Food Biochemistry 29: 470-485. 